\title{
Insights and Opportunities Offered by a Rapid Ecosystem Service Assessment in Promoting a Conservation Agenda in an Urban Biodiversity Hotspot
}

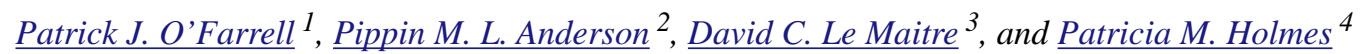

\begin{abstract}
Regional and global scale ecosystem service assessments have demonstrated the socioeconomic value of protecting biodiversity and have been integrated into associated policy. Local government decision makers are still unsure of the applicability, return on investment, and usefulness of these assessments in aiding their decision making. Cape Town, a developing city in a globally recognized biodiversity hotspot, has numerous competing land uses. City managers, with a tightly constrained budget, requested an exploratory study on the links between ecosystem services and biodiversity conservation within this municipal area. We set out to develop and test a simple and rapid ecosystem service assessment method aimed at determining the contribution natural vegetation remnants make to ecosystem service provision. We took selected services, identified in conjunction with city managers, and assessed these in two ways. First we used an area weighted approach to attribute services to vegetation types and assessed how these had changed through time and into the future given development needs. Second, we did a regulatory and cultural service remnant distance analysis to better understand proximity effects and linkages. Provisioning services were found to have been most severely affected through vegetation transformation. Regulatory services have been similarly affected, and these losses are more significant because regulatory services can only function in situ and cannot be outsourced in the way provisioning services can. The most significant losses were in coastal zone protection and flood mitigation services, both of which will be placed under even greater pressure given the predicted changes in climatic regimes. The role of remnant vegetation in regulating and cultural services was shown to be a significant additional consideration in making the case for conservation in the city. Our rapid assessment approach does not allow for nuanced and individual understanding of the trade-offs presented by individual remnant patches, but is particularly strong in quickly identifying issues, key focus areas, and opportunities provided by this research direction, and thereby serving to facilitate and drive constructive engagement between ecosystem service experts and city planners.
\end{abstract}

Key Words: Cape Town; ecosystem service tool; historical change; scenario modeling; scoping; urban ecology

\section{INTRODUCTION}

Ecosystem services are seen as a way of demonstrating the relevance and value of biodiversity to society, and the value of ecosystem service-based approaches is now, at a global scale, becoming well entrenched into national level policy (Seppelt et al. 2011). Ecosystem services assessments, however, have typically been carried out at regional scales and primarily in rural environments. Agriculture, water production, carbon sequestration services, and to a lesser extent cultural services, have formed the primary focus of these assessments (MEA 2005). These assessments have typically been large in scale, time, and people intensive, and thus expensive, as in the case of the Millennium Ecosystem Assessment (2005). Local level assessments of services remain under-explored and the urban context has received limited attention. The urban ecology underpinning this and true engagement with city-scale drivers and their effects, is still an emerging science (Pickett et al. 2001, Cadenasso and Pickett 2008). Cities are key to securing long-term global sustainability, so interest in urban ecology is growing (Piracha and Marcotullio 2003). The loss of urban green space also impacts on conservation, particularly where cities and high biodiversity levels coincide. Where this happens an additional dimension is added, and the importance of existing urban nature, its functioning and connectivity, has to be more carefully considered in the planning process (Yli-Pelkonen and Niemelä 2005).

The limited urban ecosystem services assessment work to date typically has had a northern hemisphere, developed world bias. Different cities face different issues, and developing cities within biodiversity rich areas face numerous, and specific challenges (Piracha and Marcotullio 2003). These relate to meeting local and global conservation expectations, local service delivery, and navigating the disputed territory between these as they play out around land-use allocation and associated trade-offs. What commonly emerges in developing cities is inefficient resource and land use, frequently with immediate negative environmental consequences and longer term realized negative social impacts (Piracha and Marcotullio 2003). The City of Cape Town in South Africa faces these

\footnotetext{
${ }^{1}$ Natural Resources and the Environment, Council for Scientific and Industrial Research, ${ }^{2}$ African Centre for Cities, Environmental and Geographical Science Department, University of Cape Town, South Africa, ${ }^{3}$ Natural Resource and the Environment, Stellenbosch, South Africa, ${ }^{4}$ Biodiversity Management Branch, Environmental Resource Management Department, City of Cape Town, South Africa
} 
types of difficulties, in particular motivating for biodiversity conservation at sites being promoted for development (Holmes et al. 2008). Although ecosystem services have been valued at the city scale (See De Wit et al. 2009), no spatial assessment of these services has been undertaken so clear links between the ecosystem services and the spatial representation of functioning ecosystems or natural vegetation remnants are lacking.

Cadenasso and Pickett (2008) call for ecologists to get involved in city planning with some urgency. There is a pressing need for readily available information and spatial assessment tools for city planners and managers to use to guide, or at least inform, decision making around ecosystem service and biodiversity issues. Cities are typically complex decision making environments (Piracha and Marcotullio 2003) that require novel approaches to inform decision making forums. This paper introduces and applies a rapid assessment tool as a way of conceptualizing or scoping the spatial arrangement of, and temporal engagement with, ecosystem services in Cape Town. We use existing data, informed by the particular circumstances of Cape Town, and under the directive of the city's Biodiversity Management Branch, to determine the value of the approach. We used vegetation type and cover to characterize the ecosystem generating resources, both historically and currently, and then assessed how future land use change might affect services. In addition we examined remnant distance relationships for certain services. Both the findings and the value of the tool itself are considered.

\section{STUDY AREA}

The City of Cape Town is located on the southwestern tip of southern Africa and is situated in the Cape Floristic Region, a globally recognized biodiversity hotspot (Mittermeier et al. 2005) and conservation priority (Underwood et al. 2009). The city occupies about $2460 \mathrm{~km}^{2}$, has a population of 3.7 million people, and includes 19 national terrestrial vegetation types, containing an estimated 3250 plant species, of which 190 are endemic (Rebelo et al. 2011, Holmes et al. 2012). The city has varied topography, with mountain ranges in the southwest (Table mountain range) and east (Hottentots Holland and Kogelberg ranges), a low lying central region referred to as the Cape Flats where urbanization is focused, coastal areas on the south and western edges, and agricultural areas in the northeast (Rebelo et al. 2011). The urban spatial arrangement is typical of postapartheid cities in South Africa with racially defined spatial planning (Swilling 2010) still evident and aligned with significant wealth disparities. Transforming informal settlements into formal housing is one of the key development challenges (Swilling 2006, 2010, Holmes et al. 2008).

\section{METHODS}

\section{Identifying ecosystem services}

The ecosystem service assessment team worked with the Biodiversity Management Branch of the City of Cape Town to identify the ecosystem services used in this investigation. City managers identified coastal security, water related issues, human well-being, and tourism as broad areas of concern. The managers and the project assessment team worked together to assemble available spatial data relating to ecosystem services, and looked for the potential linkages between the data and the services or issues of interest. The resources available for the analysis and assessment on this project amounted to a total of a one person week (senior scientist level).

A simple assessment method was applied to relate ecosystem service values to vegetation types, distances, and land uses. The approach was two-pronged. First we assessed a suite of provisioning and regulatory services in relation to land cover change within the City of Cape Town by contrasting three different land transformation scenarios: completely natural (no transformation), current land use (current levels of transformation), and future possible land use (projected transformation) with four ecosystem services themes, namely agricultural provision, water run-off regulation, groundwater, and coastal zone protection. Under each of these themes one or more ecosystem service indicators or surrogates were examined. This was done to provide an indication of the current state of specific ecosystem services within the city in contrast to the potential maximum level, as well as to highlight how future scenarios of land cover change could be assessed and why this is important. We drew on the approach proposed by Deal and Pallathucheril (2009) who suggest the characterization of the resource and associated services in ways that facilitate modeling the future impacts of land use change on service delivery. Non-natural remnants, although recognized as providing a suite of ecosystem services which may complement or augment those from natural remnants, were combined with formal housing in this analysis. This potentially undervalues the ecosystem service contributions from these land types and is a recognized limitation of the study.

Second, because much of the available data related to specific point localities, for example, where natural areas were in relation to potential users or beneficiaries and was not suitable for use in the land cover assessment, we developed an approach to incorporate these data. We demonstrate this by assessing a further suite of services, cultural and regulatory, in relation to their proximity to, and association with remaining natural vegetation remnants. Here we examined tourism sites, cultural sites, schools, and cultivated land associations with natural vegetation remnants. 


\section{Ecosystem service assessment associated with land cover change}

Land cover mapping: potential, actual, and future

Potential vegetation of the city was mapped using the South African National Vegetation map (Mucina and Rutherford 2006) combined with finer scale city vegetation subtype mapping (A. Stipinovich and P. Holmes, unpublished report). This layer was used as a representation of land-cover precolonial settlement, when ecological states and associated services were assumed to be at their highest potential level.

We combined this indigenous remnant vegetation layer with the National Land-Cover 2000 (Van den Berg et al. 2008) to generate what we have called an actual land use or land cover layer for the city (Fig. 1). There were some discrepancies in these layers between what was natural and what was not. This related mainly to very small fragments that the National LandCover identified as natural remnants, and these were labeled as 'unknown'. The actual land-cover layer was then combined with each of the ecosystem service layers (listed below) to assign land-use-class status to service areas and service-level weights across land use classes. No ground truthing was performed in this study because the original National LandCover 2000 had been ground validated by Van den Berg et al. (2008).

We generated an additional hypothetical land-cover layer, based on a single future scenario, both to demonstrate the potential value of an approach that introduces spatially defined future scenarios, and to determine likely changes in ecosystem service levels in the future (Fig. 1). Here we reclassified all natural vegetation remnants in the actual land cover that were not in protected areas or formally managed areas as urban or built-up (formal housing).

\section{Measuring change in services}

Although there are a variety of ways to map ecosystem services and examine changes in these over time, our emphasis on developing a simple and rapid assessment approach led us to focus on vegetation types. This is supported by Pickett and Cadenasso's (2008) argument that the functioning ecology of a city is hinged primarily on the presence of plants and plant communities. Yapp et al. (2010) also used a structural vegetation classification in assessing ecosystem services in Australia.

For each service we identified appropriate datasets that enabled us to quantify services. We used an area weighted approach or proportional representation, to assign service values to the vegetation types in our potential vegetation map. This allowed us to determine how service levels had changed over time according to the change in area of the vegetation type associated with actual and future land cover maps. Although we made every attempt to use data with an appropriate resolution, including the city natural vegetation
Fig. 1. Past, potential vegetation cover (a); present, current land-cover (b); and potential future land cover, if all natural remnants, not formally protected, were converted to formal housing (c) for the City of Cape Town.

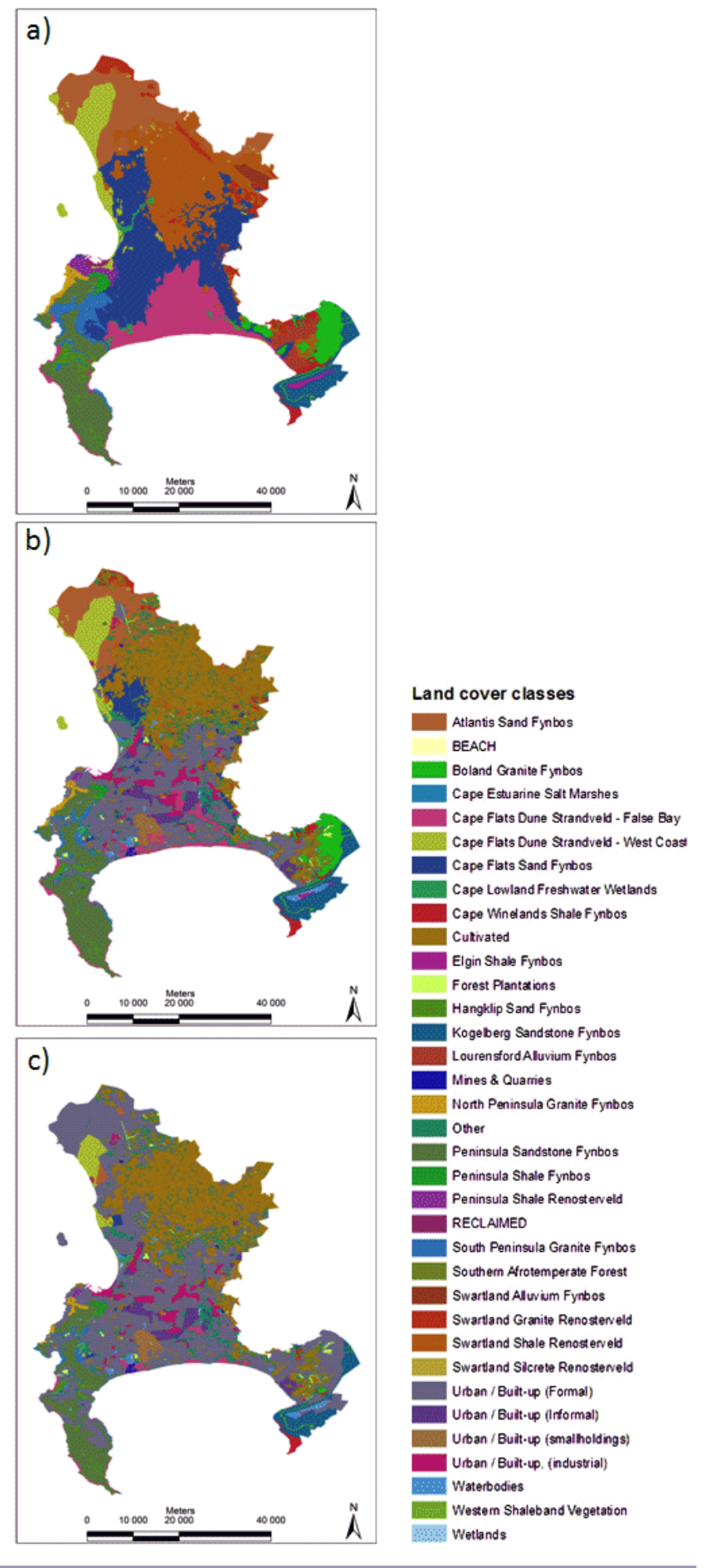


remnants layer that was ground truthed for habitat condition, some datasets developed at the national scale had to be utilized, and may only be considered to provide a broad (generalized) overview when used at this scale, a further limitation of our selected approach.

\section{Agricultural provisioning services}

Although provisioning services were excluded from the initial discussions, we have included two of these services in our analysis, to demonstrate historical changes. Furthermore, these services may become increasingly important under conditions of climate change, in which food security may become a more localized concern.

Land capability: We used the Land Capability data set (Agricultural Research Council 2002) as an index of agricultural potential within the city. This data set divides the national land surface into eight classes, ranging from $1=$ very high potential, to $8=$ very low potential.

Grazing potential: The relative value of the land for livestock production was estimated by calculating the grazing potential of each vegetation type. This potential was derived from Scholes' (1998) national estimates of sustainable mean domestic livestock production. As Scholes (1998) provided categorical ranges of values we used the midpoint value of each class in assigning these values.

\section{Water run-off regulation}

Soil retention: Natural vegetation is important for stabilizing wind and water erosion prone soils (Gordon et al. 2008). Some forms of land cover also provide a measure of this service such as formal medium-density urban areas, however other land cover classes do not provide this services as effectively, for example, cultivated land when poorly managed (Van Noordwijk et al. 2004). We used the soil erodibility factor defined and mapped by Schulze and Horan (2007). They assigned each soil type (bare soils) within South Africa with an erodibility factor $(\mathrm{K})$, ranging from 0.1 (soils with a low erodibility) to 0.7 (soils with a high erodibility). We developed a soil erodibility data layer for all vegetation types within the city.

Critical infiltration zone mapping: Infiltration is a critical factor in rain water capture by the soil and a key factor in reducing overland run-off and flood peaks as well as recharging catchment water storage and sustaining river flows in the dry season (Gordon et al. 2008). There are synergies between this service and the flood mitigation service. We developed a critical infiltration zone data layer using a national rainfall coverage (Schulze 2007) and selecting areas of high and most intense rainfall ( $800 \mathrm{~mm}$ and above) as priority areas for ensuring maximum possible infiltration. All vegetation types that fell within these areas were assumed to have the same weighting.
Flood mitigation zone mapping: We developed a flood mitigation zone layer for the city using a number of different spatial datasets. We took the national 1:500,000 rivers (large river systems) of the country and the 1:500,000 wetlands (see Nel et al. 2011), and selected those that fell within the city boundary. We created a $50 \mathrm{~m}$ buffer for these rivers. A 1:50,000 rivers dataset (smaller river systems) for the city was buffered by $32 \mathrm{~m}$ (DLA-CDSM 2007). The two river layers were merged with the flood prone areas data layer provided by the city, also buffered with a $50 \mathrm{~m}$ buffer, to create a single layer, which we call 'the flood mitigation zone.' This is an area that should remain undeveloped so as to allow for flood water spreading, infiltration, and calming. This area also is important for its potential to act as a buffer for improving the quality of water run-off from nonpoint sources of pollution.

\section{Coastal zone protection}

Natural vegetation and dune systems, particularly the foredune, play key roles in buffering the coastline against the impacts of periodic storms (Barbier et al. 2011). We developed a coastal zone protection layer based on the Integrated Coastal Management Act (Republic of South Africa 2008) recommendation of a $1000 \mathrm{~m}$ "no development zone" along coastlines, by buffering the city's coastline. We then calculated the areas for all land use classes for each of the three layers to obtain the predevelopment total area by vegetation type in this zone and the degree to which this has changed.

\section{Groundwater recharge, yield, and quality}

Groundwater recharge: Groundwater recharge is critical for sustained river flows in the dry season, for certain vegetation communities, and potential or actual human use for a range of purposes (Colvin et al. 2007, Scanlon et al. 2007). We used the national groundwater recharge data layer from a groundwater resource assessment (DWAF 2005).

Groundwater yield: We used city scale groundwater borehole yield data in liters per second as service values (City of Cape Town 2002). The borehole yield is a direct measure of the potential for groundwater abstraction and use.

Groundwater quality: We used the groundwater conductivity values $(\mathrm{mS} / \mathrm{m}$ ) to define classes (City of Cape Town 2002). Water quality determines the amount and cost of treatment required to purify it for human use so high quality water is of great value.

\section{Integrated service analysis}

To determine the level of service delivery generated by each vegetation type, and current and future land use or status, an expert group consisting of five senior scientists, all experts in fields associated with the selected services, scored cards of land use types in association with ecosystem services (between 0 - 10). Scores were then averaged, and are presented in Table 1. The land use types included here were: natural vegetation in high (good), medium, and poor condition, cultivation, 
Table 1. Ecosystem services scored for different land use classes based on expert opinion. Scores were rated on a scale from 0 to 10 where 0 represented no service and 10 the maximum potential service.

\begin{tabular}{|c|c|c|c|c|c|c|c|c|c|c|c|}
\hline Ecosystem service & $\begin{array}{l}\text { Natural } \\
\text { vegetat- } \\
\text { ion } \\
\text { good } \\
\text { condition } \\
\text { (High) }\end{array}$ & $\begin{array}{l}\text { Natural } \\
\text { vegetat- } \\
\quad \text { ion } \\
\text { average } \\
\text { condition } \\
\text { (Mediu- } \\
\text { m) } \\
\end{array}$ & $\begin{array}{c}\text { Natural } \\
\text { vegetat- } \\
\text { ion poor } \\
\text { condition } \\
\text { (Poor) } \\
\end{array}$ & $\begin{array}{c}\text { Cultiva- } \\
\text { ted }\end{array}$ & $\begin{array}{c}\text { Forest } \\
\text { Plantat- } \\
\text { ions }\end{array}$ & $\begin{array}{c}\text { Urban / } \\
\text { Built-up } \\
\text { (indust- } \\
\text { rial) }\end{array}$ & $\begin{array}{c}\text { Urban / } \\
\text { Built-up } \\
\text { (formal } \\
\text { housing) }\end{array}$ & $\begin{array}{l}\text { Urban / } \\
\text { Built-up } \\
\text { (informal } \\
\text { housing) }\end{array}$ & $\begin{array}{l}\text { Urban / } \\
\text { Built-up } \\
\text { (smallh- } \\
\text { oldings) }\end{array}$ & $\begin{array}{c}\text { Mines } \\
\& \\
\text { Quarries }\end{array}$ & Unknown \\
\hline Land capability & 10 & 9 & 8 & 10 & 10 & 0 & 0 & 0 & 10 & 0 & 8 \\
\hline Grazing & 10 & 6 & 3 & 0 & 0 & 0 & 0 & 0 & 0 & 0 & 0 \\
\hline Flood mitigation & 10 & 9 & 7 & 5 & 9 & 0 & 5 & 3 & 8 & 0 & 5 \\
\hline Soil retention & 10 & 8 & 7 & 7 & 9 & 10 & 9 & 5 & 9 & 0 & 5 \\
\hline Critical infiltration & 10 & 8 & 5 & 8 & 9 & 0 & 8 & 5 & 8 & 0 & 5 \\
\hline Coastal zone protection & 10 & 8 & 5 & 2 & 7 & 5 & 3 & 2 & 3 & 0 & 2 \\
\hline Groundwater recharge & 10 & 9 & 7 & 7 & 5 & 2 & 6 & 4 & 6 & 5 & 7 \\
\hline Groundwater yield & 10 & 9 & 7 & 9 & 5 & 2 & 6 & 4 & 9 & 5 & 7 \\
\hline Groundwater quality & 10 & 10 & 10 & 6 & 9 & 4 & 7 & 5 & 5 & 5 & 6 \\
\hline
\end{tabular}

forestry plantations, urban industrial, urban formal housing, urban informal housing, urban small holdings, mining and quarries, and unknown. The unknown category was scored as either being cultivated or natural in poor condition, based on firsthand knowledge of a sample of these fragments. The product of the vegetation type ecosystem service value and the land use score was then calculated for each of the nine ecosystem services. This process, in essence, combines the contribution of the original vegetation type with the associated land use and ecosystem service levels, and land use changes and captures their associated ecosystem service effects, for the past, present, and future scenarios. Values were then proportionally weighted between 0 and 1 , and mapped according to the current land cover of the city.

\section{Proximity of remnant to beneficiaries}

\section{Pollination service potential}

We took the natural remnant data layer supplied by the city and created a $250 \mathrm{~m}$ gridded surface layer. We then calculated the distance from each grid cell classified as natural to the nearest land class area of cultivated land. We then selected natural remnants that were within $0-0.5,0.5-5$, and $5-10$ $\mathrm{km}$ based on known solitary and honey bee foraging distances (Beekman and Ratnieks 2001, Gathmann and Tschamtke 2002). This approach excludes bees that are moved in hives for commercial gain.

\section{Cultural features}

We took the created $250 \mathrm{~m}$ gridded surface layer of remnants and combined it with a cadaster layer, of all the heritage sites supplied by the city's heritage department. We calculated the distance from each grid cell classified as natural to the nearest land class area designated as a heritage site. All natural remnants areas within $1 \mathrm{~km}$ of a heritage site were selected, assuming that visitors to heritage sites may be interested in natural remnant areas if they were within close proximity or walking distance.

\section{Tourism services}

We acquired a tourism routes data layer from the city's tourism branch that consisted of three known routes with stop-off points within the city. This data layer was combined with the gridded natural remnant data layer and used to estimate the distance from each natural remnant to stop-off points. Using our knowledge we added additional points to one of the routes. We selected all natural vegetation remnants that are within $500 \mathrm{~m}$ of tourism route stop-off points. This distance was decided on by the project team and requires testing.

\section{Education service potential}

We took the natural remnant data layer, retaining only areas protected or managed as conservation areas and containing portions of river systems in natural condition and created a $250 \mathrm{~m}$ gridded surface layer. A schools database supplied by the city was used to calculate distances between remnants and schools. Remnants that were within a walking distance of 1 $\mathrm{km}$ of schools were plotted based on a small sample of known activities of this nature. The factors guiding exclusions may need to be reconsidered, but we excluded areas in a poor ecological state because these are less attractive to schools owing to lower biodiversity values and perceived pupil and staff safety issues.

\section{RESULTS}

\section{Ecosystem service assessment associated with land cover change}

The potential or original vegetation cover for the City of Cape Town (Fig. 1a) is considered to provide optimal potential ecosystem service delivery for the suite of selected services. 
The current land use for the City of Cape Town (Fig. 1b) represents current ecosystem service delivery from natural remnants. The marked topography in parts of the city has focused development and transformation in the lowland areas. The mountainous areas have remained largely intact (Fig. 1b). The future scenario of conversion of unprotected natural vegetation remnants to formal housing further entrenches this pattern because unprotected areas that could be transformed occur mainly in low lying areas (Fig. 1b).

There are marked changes in ecosystem service delivery between the original and current potential of the area, as well as projected service delivery under the future scenario described above (Fig. 2). The greatest reduction is in the grazing potential (49\%), followed by land capability (32\%), and flood mitigation (32\%). Further reductions (additional $20 \%$ ) are anticipated in grazing potential and land capability in the future. The future degree of change in the flood mitigation service may seem relatively small, but it is primarily the lower lying and flatter areas that are more at risk of flooding. The coastal protection zone has also decreased $25 \%$ because of land cover transformation, so too groundwater quality (27\%), yield (20\%), and recharge (20\%), and further decreases in these services are anticipated under the future scenario. Soil retention has changed relatively little because most of the area with $>800 \mathrm{~mm}$ of rainfall is on slopes too steep to develop, on soils with little agricultural value, or in protected areas.

Fig. 2. Changes (present) and potential changes (future) in ecosystem service supply shown as a percentage of the potential service produced.

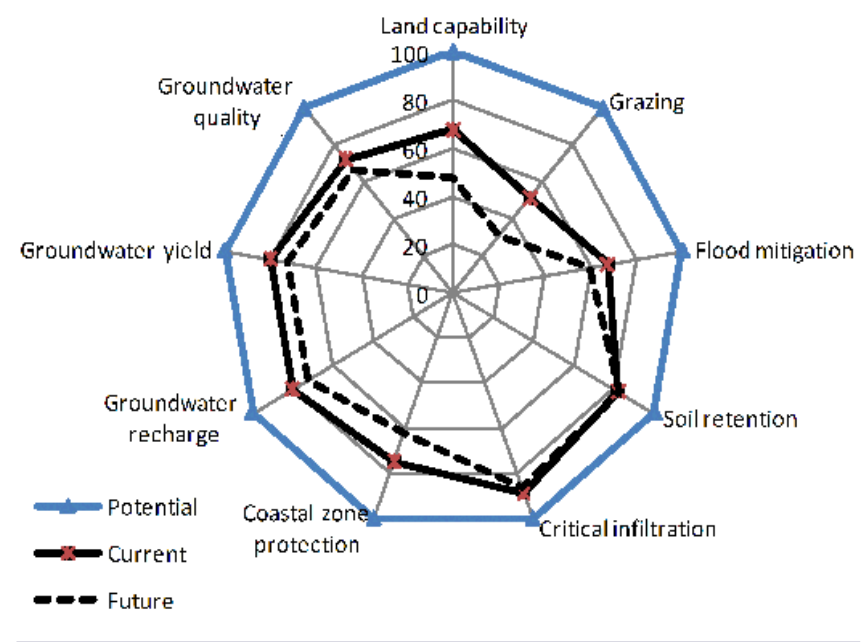

The mapped ecosystem services highlight the degree to which services differ in their nature, but are generally affected by urban and agricultural transformation. An assessment of natural remnants indicates that much of the best agricultural and grazing land within the city has been converted to urban areas, or is under cultivation (Fig. 3a,b). This broad overviewhighlights the inherently low stocking rates of the Cape Flats, mainly because the soils are infertile sands with fynbos that provide low quality grazing. The high capacity in the mountain areas and the southern western peninsula is probably due to the errors in the underlying data.

Natural vegetation generally provides the highest level of soil retention, preventing it from eroding and filling storm water systems and rivers with sediments (Fig. 3c). The scarring produced by soil erosion is generally highly visible and detracts from the aesthetic value. The critical infiltration areas within the city (Fig. 3d) play an important role in absorbing large volumes of rain water. This diminishes peak flood flows and is released during the dry season to sustain flows in the river systems. We have highlighted the areas with $>800 \mathrm{~mm}$ per year but lower rainfall areas also play a role. The city's flood mitigation zone (Fig. 3e) highlights the rivers systems and the extensive coastal wetlands that once characterized Cape Town (Fig. 1a). Much of this has been filled in and built up such as the coastline of Table Bay. The quality of this service is directly related to land use, with urban industrial areas, informal housing, and cultivation having the most severe effects.

The natural vegetation in the coastal protection zone (Fig. 3f) provides an important buffer that absorbs wave induced storm damage. This highlights those coastal areas that have been developed predominantly for housing and industry.

The highest groundwater yielding areas are the coarse sands of dunes in the northwestern areas and the southern areas (Fig. $3 \mathrm{~h})$. Unfortunately much of the groundwater in the southern region has become polluted, which reduces its value as a water source. The groundwater recharge potential for the city is strongly linked to the rainfall and also to the permeability of the rock formations and the associated soils (Fig. 3g). Sandstone and granite-derived soils have higher recharge potential than shale soils. The low potential on the highly permeable sand of the Cape Flats is largely due to the low rainfall in these areas. The areas with the best groundwater quality coincide with areas of sandstone fynbos on the Cape Peninsula and in the Kogelberg, and on adjoining granite fynbos areas (Fig. 3i). The Atlantis Sand Fynbos in the north also has particularly high water quality and coincides with high yields, indicating the importance of this area for both current and future extraction. The poorest quality groundwater is found on shale associated vegetation types in the east and Cape Flats Sand Fynbos in the west. The urban small holding area in the south stands out as polluted, possibly due to high nitrogen and phosphorous levels from vegetable farming. Informal settlements also appear to cause a decrease in water quality in this area. 
Fig. 3. Maps of current ecosystem services based on individual service values associated with vegetation types and land transformation. Services values are weighted between 0 and 1 and plotted using Jenks natural breaks. Service include a) Land capability, b) Grazing provision, c) Soil retention, d) Critical infiltration, e) Flood mitigation, f) Coastal protection, g) Groundwater recharge, h) Groundwater yield, i) Groundwater quality.

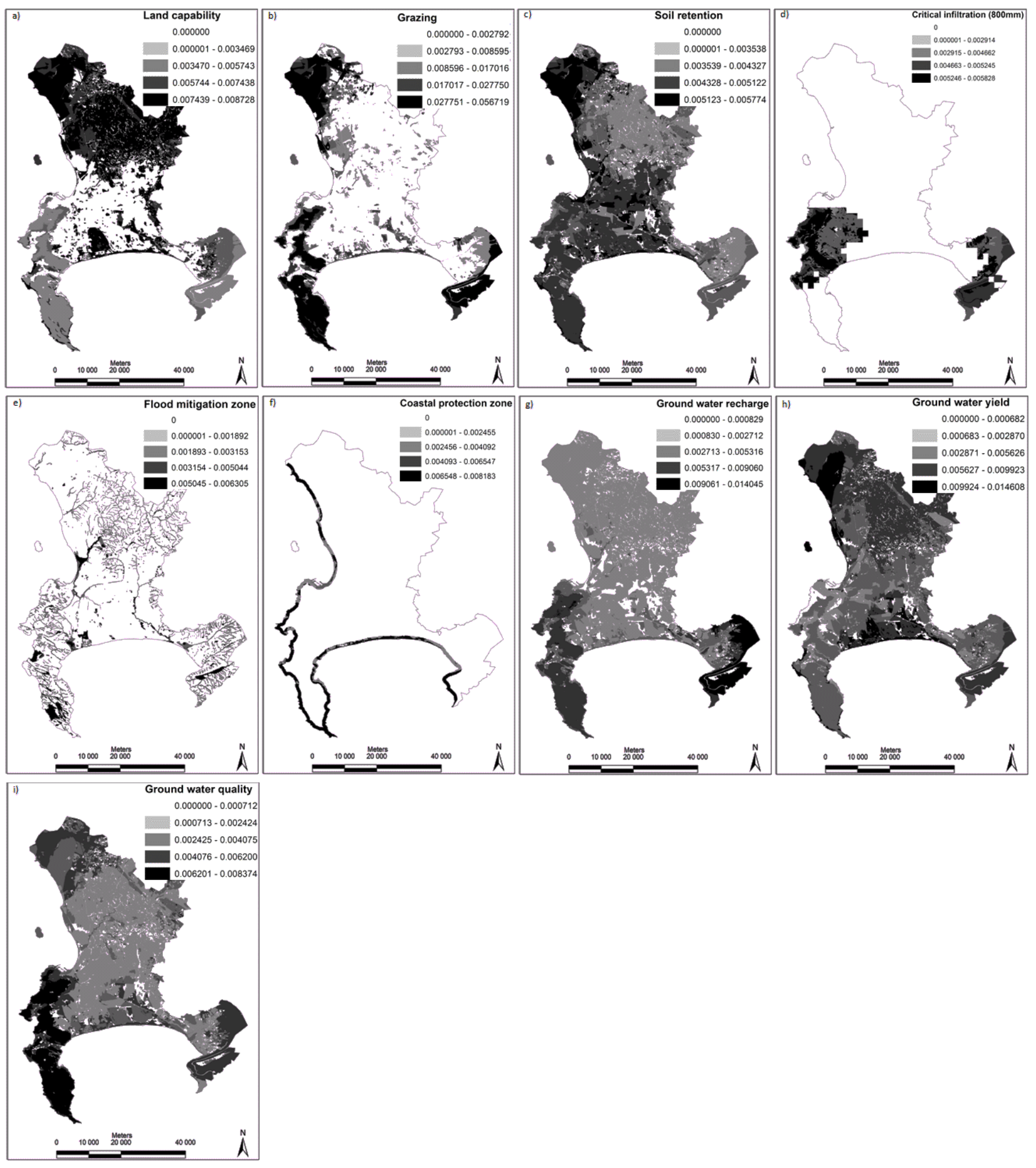


Fig. 4. Natural remnant vegetation association with distance from a) agricultural sites, b) cultural sites, c) tourism stop-off points, d) schools.
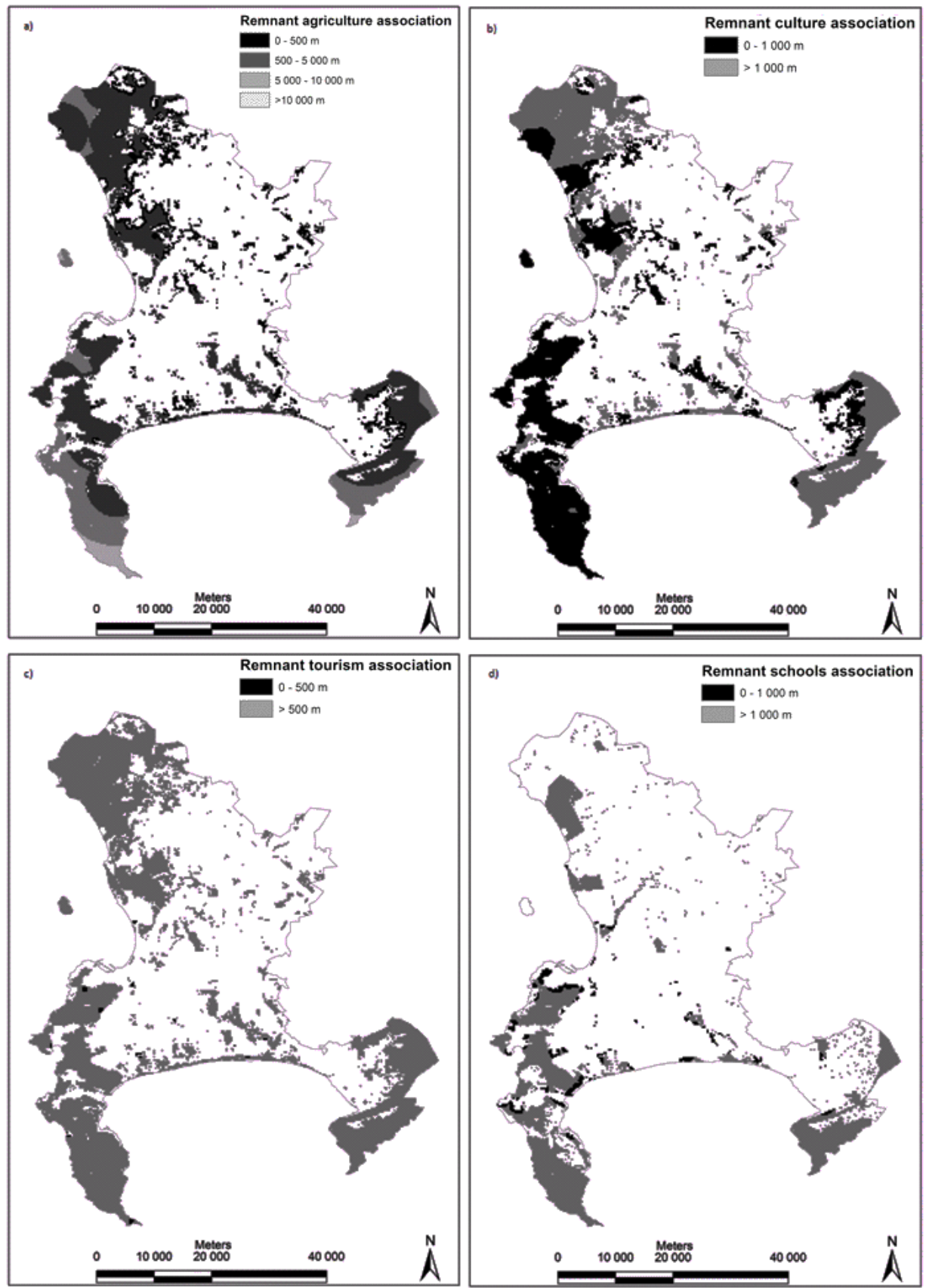

\section{Remnant location service assessment}

Although only a small proportion of the remaining natural area is included in solitary bee foraging, the majority of natural remnants are captured by the long distance pollination class or honey bees of up to $10 \mathrm{~km}$ from a remnant (Fig. 4a). Natural remnants that are within $1 \mathrm{~km}$ of cultural heritage features are highlighted in Figure 4b. A number of large natural remnants have been classified by city officials as cultural sites and this accounts for the extensive nature of this category/class. The relationship between natural remnants and stop-off points on designated tourism routes (Fig. 4c) shows that a number of natural remnants are located relatively close to tourist stopoff points. The spatial extent is constrained by the distance tourists are likely to walk, which we set at $500 \mathrm{~m}$. The relationship between natural remnants and city schools shows key areas situated within the City Bowl and the southwestern 
Cape Peninsula coastal region (Fig. 4d). There are few easily accessible remnants in the low lying Cape Flats and the more extensive and better protected and conserved remnants are far from those schools. The access problem is further exacerbated by the fact that this is a low income area and the schools cannot afford transport. The walking threshold distances proposed here of $1 \mathrm{~km}$ to remnants could be adjusted to include other means of transport and their associated costs.

\section{DISCUSSION}

This rapid assessment must be viewed in the context of Cape Town as a recognized biodiversity hotspot (Myers et al. 2000). As such, the assessment set out to establish not whether biodiversity supplies ecosystem services, but rather whether the natural remnants within the city supply provisioning, regulating, and cultural services that could justify their continued existence as well as meeting critical conservation goals. The method adopts a pragmatic, rather than a purely conservation-driven approach by explicitly including the flow of services from various land uses and not just conservation areas as suggested by Piracha and Marcotullio (2003) and Palmer et al. (2004). For example, cultivated lands contribute to infiltration, though to a lesser degree than natural vegetation and this is acknowledged in the weighting of scores. Therefore, although some of these transformed spaces may not contribute directly to the important repository of species to be conserved, they do form part of a larger multifunctional matrix of space in the city, and most certainly contribute to ecosystem service delivery and ecological functioning. In this assessment natural vegetation always scored the maximum amount, but this is unlikely to be the case in all areas, for all services. In some instances transformed areas are likely to surpass natural vegetation, as is the case for crop production.

\section{Provisioning outsourced}

The temporal assessment shows that provisioning services have been critically compromised with the loss of grazing and land capability, largely because of the geographical position of these services on the low-lying lands that are also most readily transformed to housing. With much of the provisioning services now outsourced beyond the city boundary the loss of these services is largely unimportant. For example, water is predominantly sourced from outside the city (Quick 1995, Gasson 2002, as cited in Swilling 2006), and, because urban expansion has reduced available land for agriculture (del Mar Lopez et al. 2001, Anderson and O'Farrell 2012), produce is primarily brought into the city from outlying agricultural areas and further abroad (Gasson 2002, as cited in Swilling 2006). These trends, whereby the provisioning services that support a city are sourced beyond that city boundary, has been noted globally (Folke et al. 1997, Gutman 2007, Grimm et al. 2008). The fact that the areas that supply these services are also not adequately compensated for them is at the heart of many debates about payments for ecosystem services (Gutman 2007). The temporal view taken in this assessment, which shows both potential service delivery and actual service delivery, demonstrates this shift from an emphasis on provisioning to one on regulatory services in the city, in keeping with other historical narratives (Anderson and O'Farrell 2012).

\section{Regulatory services in situ}

Far more critical than the loss of provisioning services, which can be sourced elsewhere, is the substantial erosion of regulating services. Regulatory services are critical to city sustainability, can only be delivered in situ, and are generally of a scale that cannot be readily substituted with engineered infrastructure. The most significant loss has been in coastal zone protection and flood mitigation services. The consequence of the loss of coastal buffering will be felt in the future with predicted climate-related change, where sea-level rise combined with increased storm strengths can increase the risk of extreme wave conditions and consequent damage (Cartwright 2008, Theron et al. 2010, Barbier et al. 2011). Although this is a qualitative model, it suggests that sanctioning any further reduction in reserve land in this coastal protection zone would be unwise. The same can be said for flood plain infiltration and associated flood mitigation. The consequences of the reduction in this service are already felt by many in the low lying areas of the city near rivers. These remaining natural remnants should come under the strictest of land cover change controls to ensure the continued delivery of this mitigatory regulating service. This is particularly important given that the beneficiaries of this service are some of the most vulnerable and economically marginal in the city (Govender et al. 2011, Musungu et al. 2012). Although little information is available on actual pollination services or their importance within the city, our analysis highlights likely areas of importance for this service, according to two different pollinator groups.

\section{Cultural dimension, distance, and accessibility}

The examination of the distance relationships between remnants and broader society shows good potential for building a case based on cultural heritage and educational service potential. The inclusion of cultural services in the form of education and heritage in this study is based on the recognized importance of cultural service provision in the city, where remnant green spaces provide opportunities for urban dwellers to have contact with nature, which has numerous benefits. These include education about the environment and natural or cultural heritage, enhanced mental-health in response to space for recreation and relaxation, improved aesthetics, space to pursue religious or cultural rituals, cushioning of noise and air pollution, and the potential for inclusion in a tourism industry with economic benefits (YliPelkonen and Niemelä 2005).

Reflections on the loss of natural land, most pronounced on the lowlands or Cape Flats, immediately highlights the potential value of such remnant patches to neighborhoods and 
their schools. Research has found that urban fragments are of value to inner city schools and residents (Britton and Jackelman 1995, Le Maitre et al. 1997, Ashwell 2010) and education is a viable 'hook' on which to build a case for conservation. This study demonstrates diminishing opportunities for the numerous schools on the lowland areas to access natural land and a growing scarcity of opportunities for the provision of associated cultural services. There are opportunities for forging links between schools and remnant patches with a view to securing the future of biodiversity in these remnants and with positive benefits for the schools (Britton and Jackelman 1995, Manuel 2006). The inhabitants hold the key to securing the sustainability of the city and the inclusion of this social dimension in this rapid assessment has proved valuable and warrants greater attention in future.

Although, at a broad scale the natural environment most certainly contributes to Cape Town's tourism appeal, on a remnant scale this was not a significant driver. This assessment demonstrates that mass tourism, in its current form, does not present a viable 'hook' or case on which to motivate for the conservation of all remnant green spaces. Some of the remaining remnants are impressive from a scenic and biodiversity point of view, but are off current tourism routes. Strategic marketing campaigns that possibly linked these remnants with township tours may be a plausible strategy. It is also possible that a more specialized and focused form of tourism, targeting biologists, could be viable.

\section{Ecosystem services arguments for urban conservation}

This assessment indicates some very clear opportunities for invoking ecosystem services in motivating natural remnant conservation. Absorption of storm waves, for example, is clearly a critical regulatory service and a strong case can be made for coastal dune protection on this basis. The multiple service approach highlights the potential for building a case for using ecosystem service 'bundles' for the retention of natural remnants and green space, and the value of including a variety of services (Bennett and Balvanera 2007). The use of multiple layers demonstrates that a case can be made for a great number of critical remnants based on some ecosystem service. For example one area may serve as seasonal flood protection and also hold potential education value by its proximity to schools in an otherwise highly built up area. Or an area might not hold any tourism potential, but can be shown to be close to other remnants that warrant attention for the preservation of pollination services. The addition of a cultural service, and associated accessibility layer, supports the use of multiple services to demonstrate the societal value of remnants. It is worth noting that in some instances the ecosystem services argument will not gain sufficient purchase and here conservation must be fought on a different level, speaking to national responsibility and global biodiversity concerns. This method can readily demonstrate where those singular cases might be, and in turn different arguments can be mobilized around these remnants.

The spatial arrangement of ecosystem service delivery is clearly presented through this method. The evident erosion of services through time demonstrates a history of urban planning taking place without cognizance of the importance of urban nature in ensuring city sustainability and resilience. Both current and future land use and environmental changes highlight the vital importance of regulatory services. If the scenario of developing all unconserved natural land in the city becomes reality, it could result in significant further loss if we fail to achieve densification and continue with urban sprawl. There is a critical need for spatial planning to engage with the various layers produced in an assessment such as this. Although any urban planning exercise and associated development initiative will require inevitable trade-offs such as ecosystem services in favor of housing, it is important that these trade-offs be informed. This is particularly pertinent to Cape Town, where the natural environment has a high biodiversity irreplaceability value and as a result the city presents a low choice environment where spatial planning decisions must be made under constrained circumstances. The option of matching ecosystem services and conservation targets, used for example by Egoh et al. (2011), cannot be exercised. In this minimal choice environment, prioritizing on the basis of ecosystem services and selecting only those sites of highest values, is potentially problematic from a biodiversity perspective. Although defining biodiversity hotspots may be a valuable approach in conservation prioritization, it is not necessarily a good approach for ecosystem services in the urban setting. In a hotspot such as Cape Town, biodiversity must lead over ecosystem services in building the conservation case.

\section{The value of a rapid assessment tool}

What emerges from this rapid assessment is not a full or complete ecosystem service assessment or inventory. In the same way as a scoping study would precede an environmental impact assessment, we argue that a rapid assessment such as this should precede a full ecosystem service assessment. This rapid assessment technique should be seen as a scoping tool highlighting areas where ecosystem services have been particularly adversely affected. Although this analysis may be limited by available biological and social data, such as tourist walking distance preferences, it is fairly simple to apply. Furthermore its use and implementation do not require dedicated training for users as in the case of other more sophisticated approaches and tools such as INVEST (Daily et al. 2009).

The value of a scoping tool is that it can quickly derive the status quo, and simultaneously generate a platform for the formation of a common language and understanding to guide future discussions. In turn, areas of contention or contradictory 
circumstances, common when making ecological and social decisions, are issues quickly brought to light and can be readily addressed (Haila 1995). The development of this initial macro spatial and temporal scale understanding could in turn be used to direct more detailed assessment such as those proposed by Cowling et al. (2008) or foregrounding of various agendas. For example, it would be easy to run a scenario based on a housing development agenda (Turok and Watson 2001), or one to explore the specifics of climate change related impacts (Grimm et al. 2008), direct restoration efforts, or even to guide experimental design (Felson and Pickett 2005).

In the same way this tool can highlight issues and provide opportunities for focusing future work, it can also serve to demonstrate who the players are, or should be. The tool requires expert input but finds its relevance only in the hands of practitioners; as a result its success is hinged on both successful discipline-driven interdisciplinary and issue-driven interdisciplinary engagement (Max-Neef 2005, Robinson 2008). Of particular significance to its success would be engagement among the various departments within the city. It is hoped that a rapid assessment such as the one presented here could serve as a vehicle to forward both this type of engagement, and in turn, in driving discussions toward innovative new solutions deemed critical to sustainability and resilience (Parnell et al. 2009).

It must be acknowledged that South Africa has well-developed spatial datasets. This is not the case for most developing countries, and in these countries assessments of this nature would have to rely on globally produced datasets. These are often at coarse scales with poor resolution resulting in services being either grossly under or overestimated for these parameters being measured. Furthermore, rapid assessments as described here could in fact become lengthy processes when datasets need to be secured, or worse still developed, and in these instances alternative methods should be sought for assessing ecosystem services.

\section{CONCLUSION}

This study highlights the current and future potential service extent and changes within Cape Town based on natural vegetation and transformation. It demonstrates a useful rapid ecosystem services assessment method for understanding ecosystem services in an urban context at the city scale. It highlights both the value of ecosystem services to the city, in particular regulatory services, and shows where services are being eroded. The method shows potential to generate scenarios and assess specific ecosystem services, for example with further loss of specific vegetation types. The remnant distance analysis shows the value of considering multiple ecosystem services in building conservation arguments. Our scale of assessment does not allow for the nuanced and individual understanding of associated trade-offs presented by individual patches, and although it could be adapted to do so this would typically require more time and resources. Last, this method has the potential to facilitate and drive constructive engagement between ecosystem service experts and city planners, a crucial condition for urban sustainability.

Responses to this article can be read online at: http://www.ecologyandsociety.org/voll7/iss3/art27/ responses/

\section{Acknowledgments:}

This paper is a product of the Urban Ecology CityLab which is part of the CityLab programme of the African Centre for Cities at the University of Cape Town. The African Centre for Cities' CityLab programme is funded through the Mistra Urban Futures network (which is funded by Mistra the Foundation for Strategic Environmental Research and the Swedish International Development Cooperation Agency), the Provincial Government of the Western Cape (Department of Human Settlements), and the City of Cape Town.

\section{LITERATURE CITED}

Agricultural Research Council. 2002. A system for soil and land capability classification for agriculture in South Africa. Department of Agriculture and Environmental Affairs, Pretoria, South Africa.

Anderson, P. M. L., and P. J. O'Farrell. 2012. An ecological view of the history of the establishment of the City of Cape Town. Ecology and Society 17(3):28. http://dx.doi.org/10.5751/ ES-04970-170328

Ashwell, A. 2010. Teens need nature too: programmes, poetry and possibilities in the City of Cape Town. Proceedings of the Healthy Parks Healthy People Conference, Melbourne, Australia. [online] URL: http://www.hphpcentral.com/?s=ashwell

Barbier, E. B., S. D. Hacker, C. Kennedy, E. W. Koch, A. C. Stier, and B. R. Silliman. 2011. The value of estuarine and coastal ecosystem services. Ecological Monographs 81:169-193. http://dx.doi.org/10.1890/10-1510.1

Beekman, M., and F. L. W. Ratnieks. 2001. Long-range foraging by the honey-bee, Apis mellifera L. Functional Ecology 14(4):490-496. http://dx.doi.org/10.1046/j.1365-243 5.2000.00443.x

Bennett, E. M., and P. Balvanera. 2007. The future of production systems in a globalized world. Frontiers in Ecology and the Environment 5:191-198. http://dx.doi.org/10.1890/15 40-9295(2007)5[191:TFOPSI]2.0.CO;2

Bolund, P., and S. Hunhammar. 1999. Ecosystem services in urban areas. Ecological Economics 29(2):293-301. http://dx.d oi.org/10.1016/S0921-8009(99)00013-0 
Britton, P., and J. Jackelman. 1995. Wolfgat Nature Reserve. Veld \& Flora 81(2):46-48.

Cadenasso, M. L., and S. T. A. Pickett. 2008. Urban principles for ecological landscape design and management: scientific fundamentals. Cities and the Environment 1(2):1-16.

Cartwright, A. 2008. Global climate change and adaptationa sea-level rise risk assessment. Phase three: Final Report A Sea-Level Rise Risk Assessment for the City of Cape Town. Stockholm Environment Institute, Stockholm, Sweden.

City of Cape Town. 2002. The environmental significance mapping project, GEOSS - Geohydrological and Spatial Solutions. Environmental Resource Management Department, City of Cape Town, Cape Town, South Africa.

Colvin, C., D. Le Maitre, I. Saayman, and S. Hughes. 2007. An introduction to aquifer dependent ecosystems in South Africa. WRCReport TT 301/07, Water Research Commission, Pretoria, South Africa.

Cowling, R. M., B. Egoh, A. T. Knight, P. J. O'Farrell, B. Reyers, M. Rouget, D. J. Roux, A. Welz, and A. WilhelmRechman. 2008. An operational model for mainstreaming ecosystem services for implementation. Proceedings of the National Academy of Sciences of the United States of America 105(28):9483-9488. http://dx.doi.org/10.1073/pnas.0706559105

Daily, G. C., S. Polasky, J .Goldstein, P. M. Kareiva, H. A. Mooney, L. Pejchar, T. H. Ricketts, J. Salzman, and R. Shallenberger. 2009. Ecosystem services in decision making: time to deliver. Frontiers in Ecology and the Environment 7:21-28. http://dx.doi.org/10.1890/080025

Deal, B., and V. G. Pallathucheril. 2009. Sustainability and urban dynamics: assessing future impacts on ecosystem services. Sustainability 1:346-362. http://dx.doi.org/10.3390/ $\underline{\mathrm{su} 1030346}$

del Mar Lopez, T., T. M. Aide, and J. R. Thomlinson. 2001. Urban expansion and the loss of prime agricultural lands in Puerto Rico. Ambio 30(1):49-54.

Department of Land Affairs - Chief Directorate: Surveys and Mapping (DLA-CDSM). 2007. 1:50 000 inland waterbodies and rivers. DLA-CDSM, Mobray, South Africa.

Department of Water Affairs and Forestry (DWAF). 2005. Groundwater resource assessment II. DWAF, Pretoria, South Africa.

De Wit, M. P., H. Van Zyl, D. J. Crookes, J. N. Blignaut, T. Jayiya, V. Goiset, and B. K. Mahumani. 2009. Investing in natural assets. A business case for the environment in the City of Cape Town. Report prepared for the City of Cape Town, Cape Town, South Africa. [online] URL: http://www.capetown. gov.za/en/EnvironmentalResourceManagement/publications/
Docum ents/EnvResEconomics-Final_Report_2009-08-18. pdf

Egoh, B. N., B. Reyers, M. Rouget, and D. M. Richardson. 2011. Identifying priority areas for ecosystem service management in South African grasslands. Journal of Environmental Management 92(6):1642-1650. http://dx.doi.o $\mathrm{rg} / 10.1016 / j . j e n v m a n .2011 .01 .019$

Felson, A. J., and S. T. A. Pickett. 2005. Designed experiments: new approaches to studying urban ecosystems. Frontiers in Ecology and the Environment 3(10):549-556. http://dx.doi.org/10.1890/1540-9295(2005)003[0549:DENATS] 2.0.CO;2

Folke, C., A. Jansson, J. Larsson, and R. Costanza. 1997. Ecosystem appropriation by cities. Ambio 26(3):167-172.

Gathmann, A., and T. Tscharntke. 2002. Foraging ranges of solitary bees. Journal of Animal Ecology 71(5):757-764. http ://dx.doi.org/10.1046/j.1365-2656.2002.00641.x

Gordon, L. J., G. D. Peterson, and E. M. Bennett. 2008. Agricultural modifications of hydrological flows create ecological surprises. Trends in Ecology \& Evolution 23:211-219. http://dx.doi.org/10.1016/j.tree.2007.11.011

Govender, T., J. M. Barnes, and C. H. Pieper. 2011. Contribution of water pollution from inadequate sanitation and housing quality to diarrheal disease in low-cost housing settlements of Cape Town, South Africa. American Journal of Public Health 101(7): e4-e9. http://dx.doi.org/10.2105/AJP H.2010.300107

Grimm, N. B., S. H. Faeth, N. E. Golubiewski, C. L. Redman, J. G. Wu, X. M. Bai, and J. M. Briggs. 2008. Global change and the ecology of cities. Science 319(5864):756-760. http:// dx.doi.org/10.1126/science.1150195

Gutman, P. 2007. Ecosystem services: foundations for a new rural-urban compact. Ecological Economics 62:383-387. htt p://dx.doi.org/10.1016/j.ecolecon.2007.02.027

Haila, Y. 1995. Natural dynamics as a model for management: is the analogue practicable? Pages 9-26 in A.-L. Sippola, P. Alaraudanjoki, B. Forbes, and V. Hallikainen, editors. Northern wilderness areas: ecology, sustainability, values. Arctic Centre Publications 7, Rovaniemi, Finland.

Holmes, P. M., A. G. Rebelo, C. Dorse, and J. Wood. 2012. Can Cape Town's unique biodiversity be saved? Balancing conservation imperatives and development needs. Ecology and Society 17(2):28. http://dx.doi.org/10.5751/ES-04552-170228

Holmes, P. M., J. Wood, and C. Dorse. 2008. City of Cape Town, biodiversity report. Local Action for Biodiversity Report, City of Cape Town, South Africa. [online] URL: htt p://www.capetown.gov.za/en/EnvironmentalResourceManagement/ 
publications/Documents/Biodiversity\%20Report\%20CCT-LAB\% 202008.pdf

Le Maitre, D., C. Gelderblom, L. Maphasa, S. Yssel, M. van den Belt, and T. Manuel. 1997. Communicating the value of fynbos: results of a survey of stakeholders. Ecological Economics 22:105-121. http://dx.doi.org/10.1016/S0921-8009 (97)00572-7

Manuel, T. 2006. Responses of different community user groups to biodiversity conservation of protected areas in lowland fynbos: the case of the Wolfgat Nature Reserve. Dissertation, University of Cape Town, Cape Town, South Africa.

Max-Neef, M. A. 2005. Foundations of transdisciplinarity. Ecological Economics 53:5-16. http://dx.doi.org/10.1016/j.ec olecon.2005.01.014

Millennium Ecosystem Assessment (MEA). 2005. Ecosystems and human well-being. Island Press, Washington, D.C., USA.

Mittermeier, R. A., P. R. Gil, and J. Pilgrim. 2005. Hotspots revisited: earth's biologically richest and most endangered terrestrial ecoregions. Conservation International, Washington, D.C., USA.

Mucina, L., and M. C. Rutherford. 2006. The vegetation of South Africa, Lesotho and Swaziland. Strelitzia 19. South African National Biodiversity Institute, Pretoria, South Africa.

Musungu, K., S. Motala, and J. Smit. 2012. Using multicriteria evaluation and GIS for flood risk analysis in informal settlements of Cape Town: the case of Graveyard Pond. South African Journal of Geomatics 1(1):77-91. [online] URL: http://www.sajg.org.za/index.php/sajg/article/view/27/11

Myers, N., R. A. Mittermeier, C. G. Mittermeier, G. A. B. da Fonseca, and J. Kent. 2000. Biodiversity hotspots for conservation priorities. Nature 403(6772):853-858. http://dx. doi.org/10.1038/35002501

Nel, J. L., A. Driver, W. Strydom, A. Maherry, C. Petersen, D. J. Roux, S. Nienaber, H. van Deventer, L. B. Smith-Adao, and L. Hill. 2011. Atlas of freshwater ecosystem priority areas in South Africa: maps to support sustainable development of water resources. Water Research Commission, Pretoria, South Africa. [online] URL: http://bgis.sanbi.org/nfepa/NFEPA At las hires.pdf

Palmer, M., E. Bernhardt, E. Chornesky, S. Collins, A. Dobson, C. Duke, B. Gold, R. Jacobson, S. Kingsland, R. Kranz, M. Mappin, M. L. Martinez, F. Micheli, J. Morse, M. Pace, M. Pascual, S. Palumbi, O. J. Reichman, A. Simons, A. Townsend, and M. Turner. 2004. Ecology for a crowded planet. Science 304:1251-1252. http://dx.doi.org/10.1126/scie nce. 1095780
Parnell, S., E. Pieterse, and V. Watson. 2009. Planning for cities in the global south: an African research agenda for sustainable human settlements. Progress in Planning 72:233-241.

Pickett, S. T. A., M. L. Cadenasso, M. J. Grove, C. H. Nilon, R. V. Pouyat, W. C. Zipperer, and R. Costanza. 2001. Urban ecological systems: linking terrestrial ecological, physical, and socioeconomic components of metropolitan areas. Annual Review of Ecology and Systematics 32:127-157. http://dx.doi. org/10.1146/annurev.ecolsys.32.081501.114012

Pickett, S. T. A., and M. L. Cadenasso. 2008. Linking ecological and built components of urban mosaics: an open cycle of ecological design. Journal of Ecology 96:8-12.

Piracha, A. L., and P. J. Marcotullio. 2003. Urban ecosystem analysis: identifying tools and methods. United Nations University Institute for Advanced Studies, Tokyo, Japan.

Quick, A. J. R. 1995. Issues facing water resource managers and scientists in a rapidly growing coastal city; Cape Town. South African Journal of Science 91:175-183.

Rebelo, A. G., P. M. Holmes, C. Dorse, and J. Wood. 2011. Impacts of urbanization in a biodiversity hotspot: conservation challenges in metropolitan Cape Town. South African Journal of Botany 77:20-35. http://dx.doi.org/10.1016/j.sajb.2010.04.006

Republic of South Africa. 2008. National Environmental Management: Integrated Coastal Management Act, (No. 24). Pretoria, South Africa.

Robinson, J. 2008. Being undisciplined: transgressions and intersections in academia and beyond. Futures 40:70-86. http ://dx.doi.org/10.1016/j.futures.2007.06.007

Scanlon, B. R., I. Jolly, M. Sophocleous, and L. Zhang. 2007. Global impacts of conversions from natural to agricultural ecosystems on water resources: quantity versus quality. Water Resources Research 43:W03437. http://dx.doi.org/10.1029/20 06WR005486

Scholes, R. J. 1998. The South African 1:250 000 maps of areas of homogenous grazing potential. Report ENV-P-C 98190, Council for Scientific and Industrial Research, Pretoria, South Africa.

Schulze, R. E., and M. J. C. Horan. 2007. Soils: hydrological attributes. In R. E. Schulze, editor. South African atlas of climatology and agrohydrology. WRC Report 1489/1/06, Section 4.2, Water Research Commission, Pretoria, South Africa.

Schulze, R. E., editor. 2007. South African atlas of climatology and agrohydrology. WRC Report 1489/1/06, Section 4.2, Water Research Commission, Pretoria, South Africa. 
Seppelt, R., C. F. Dormann, F. V. Eppink, S. Lautenbach, S. A. Schmidt. 2011. A quantitative review of ecosystem service studies: approaches, shortcomings and the road ahead. Journal of Applied Ecology 48(3):630-636. http://dx.doi.org/10.1111/ j.1365-2664.2010.01952.x

Swilling, M. 2006. Sustainability and infrastructure planning in South Africa: a Cape Town case study. Environment \& Urbanization 18:23-50. http://dx.doi.org/10.1177/095624780 $\underline{6063939}$

Swilling, M. 2010. Sustainability, poverty and municipal services: the case of Cape Town, South Africa. Sustainable Development 18:194-201. http://dx.doi.org/10.1002/sd.489

Theron, A., M. Rossouw, L. Barwell, A. Maherry, G. Diedericks, and P. De Wet. 2010. Quantification of risks to coastal areas and development: wave run-up and erosion. Conference Proceedings from Science Real and Relevant. Council for Scientific and Industrial Research, Pretoria, South Africa. [online] URL: http://researchspace.csir.co.za/dspace/b itstream/10204/4261/1/deWet 2010.pdf

Turok, I., and V. Watson. 2001. Divergent development in South African cities: strategic challenges facing Cape Town. Urban Forum 12:119-138. http://dx.doi.org/10.1007/s12132001-0013-7

Underwood, E. C., J. H. Viers, K. R. Klausmeyer, R. L. Cox, and M. R. Shaw. 2009. Threats and biodiversity in the Mediterranean biome. Diversity and Distributions 15:188-197. http://dx.doi.org/10.1111/j.1472-4642.2008.00518.x

Van den Berg, E. C., C. Plarre, H. M. Van den Berg, and M. W. Thompson. 2008. The South African national land-cover 2000. Report No. GW/A/2008/86, Agricultural Research Council (ARC) and Council for Scientific and Industrial Research, Pretoria, South Africa.

Van Noordwijk, M., J. G. Poulsen, and P. J. Ericksen. 2004. Quantifying off-site effects of land use change: filters, flows and fallacies. Agriculture, Ecosystems \& Environment 104:19-34. http://dx.doi.org/10.1016/j.agee.2004.01.004

Yapp, G., J. Walker, and R. Thackway. 2010. Linking vegetation type and condition to ecosystem goods and services. Ecological Complexity 7(3):292-301. http://dx.doi.o rg/10.1016/j.ecocom.2010.04.008

Yli-Pelkonen, V., and J. Niemelä. 2005. Linking ecological and social systems in cities: urban planning in Finland as a case. Biodiversity and Conservation 14(8):1947-1967. http:// dx.doi.org/10.1007/s10531-004-2124-7 